Marquette University

e-Publications@Marquette

Social and Cultural Sciences Faculty Research and

Publications

Social and Cultural Sciences, Department of

8-1-2017

\title{
Intersectionality and Credibility in Child Sexual Assault Trials
}

Amber J. Powell

Marquette University

Heather Hlavka

Marquette University, heather.hlavka@marquette.edu

Sameena A. Mulla

Marquette University, sameena.mulla@marquette.edu

Accepted version. Gender \& Society, Vol. 31, No. 4 (August 1, 2017): 457-480. DOI. (C) 2017 SAGE Publications. Used with permission. 


\title{
INTERSECTIONALITY AND CREDIBILITY IN CHILD SEXUAL ASSAULT TRIALS
}

\author{
AMBER JOY POWELL \\ University of Minnesota, USA \\ HEATHER R. HLAVKA \\ Marquette University, USA \\ SAMEENA MULLA \\ Marquette University, USA
}

Children remain largely absent from sociolegal scholarship on sexual violence. Taking an intersectional approach to the analysis of attorneys' strategies during child sexual assault trials, this article argues that legal narratives draw on existing gender, racial, and age stereotypes to present legally compelling evidence of credibility. This work builds on Crenshaw's (1991) focus on women of color, emphasizing the role of structures of power and inequality in constituting the conditions of children's experiences of adjudication. Using ethnographic observations of courtroom jury trials, transcripts, and court records, three narrative themes of child credibility emerged: “invisible wounds," "rebellious adolescents," and “dysfunctional families.” Findings show how attorneys use these themes to emphasize the child's unmarked body, imperceptible emotional responses, rebellious character, and harmful familial environments. The current study fills a gap in sexual assault research by moving beyond trial outcomes to address cultural narratives within the court that are inextricably embedded in intersectional dimensions of power and the reproduction of social status.

Keywords: sexual assault; children; intersectionality; testimony; court

AUTHOR'S NOTE: The authors are grateful for support from the Ronald E. McNair Scholars Program at Marquette University and for the generous feedback of three anonymous reviewers. They acknowledge the financial support from the National Science Foundation (Grant\#SES- 
1250606; IRB protocol\#HR-2224). Correspondence concerning this article should be addressed to Amber Joy Powell, University of Minnesota, 909 Social Sciences Building, $26719^{\text {th }}$ Avenue South. Minneapolis, MN 55455, USA: e-mail: powel489@umn.edu

The testimony of a child should be weighed in the same manner as the testimony of any other witness. Considerations of age, intelligence, ability to observe and report correctly, ability to understand the questions and to answer them, sense of duty to speak the truth, conduct of the witness, conduct on the witness stand, interest, appearance, and other matters bearing on credibility apply to a child witness in common with all witnesses. (Wisconsin Jury Instruction 340 as read to jury, May 30, 2013)

Judges in the Milwaukee County Circuit Court System routinely recite jury instructions during child sexual assault cases, encouraging jurors to assess children's testimony while considering "other matters bearing on credibility." These "other matters" suggest analytic nodes wherein widely shared gender, age, race, sex, and class stereotypes inhabit criminal justice practices. We are interested in how these "other matters" expose gender inequalities as they systematically intersect with multilayered oppressions. These shared cultural narratives of "other matters” are hegemonic in that they are both held by individuals but also are institutionalized in organizational structures, in laws, and in the arrangement of public space (Ridgeway and Kricheli-Katz 2013). The public space of the courtroom unfolds in a city that is 40 percent African American [1], where adjudicants are overwhelming black and Latinx, and court staff, including judges, prosecutors, defense attorneys, and clerks, are white.

With few exceptions, sociolegal scholarship has largely omitted children and youth in work on sexual violence (Whittier 2016), especially within criminal justice practices. Since 
children often are the only witness to the crime, their testimony is the featured evidence in sexual assault trials (Goodman-Delahunty, Cossins, and O'Brien 2010). Sexual assault is always gendered, as myths about sexuality influence perceptions about who can and cannot be raped (Connell 1995; Hlavka 2014). Gendered bodies are seen and interpreted as either penetrating or penetrated (Butler 1993). While feminist scholarship examines the revictimization of adult women within the legal system (Estrich 1987; Spohn and Tellis 2014), children's experiences remain on the periphery (Hlavka 2014; Whittier 2016). Scholarship neglects dimensions of power, such as age, gender, race, class and sexuality that shape victims' experiences and criminal justice processes (Collins 2004; Crenshaw 1991; Donovan and Williams 2002; Whittier 2016). These aspects of identity are not compartmentalized into discreet categories, but are overlapping and conflicting (Cho, Crenshaw, and McCall 2013). Crenshaw’s (1991) pioneering work demonstrates the interlocking oppressions that women of color experience as victims of violence located within institutional formations that shape legal subjectivity and reify power relationships. This article builds on Crenshaw's focus on women of color, examining how categories of gender, race, age, sexuality, and class are "always in the process of creating and being created by dynamics of power” (Cho, Crenshaw, and McCall 2013, 795). Set in the Milwaukee County Courthouse, this work emphasizes the role of structures of power and inequality in constituting the conditions of children's experiences of adjudication. Through an intersectional analysis, we recast children’s multilayered and marginalized identities within routinized forms of domination (Choo and Ferree 2010; Crenshaw 1991).

For this study, the authors draw data from sexual assault jury trials involving child victim-witnesses [2], a group rarely studied within the ethnographic context of the courtroom. The study explores the ways defense attorneys use commonly held beliefs to suggest the "other 
matters bearing upon credibility” across three common themes: invisible wounds; rebellious adolescents; and dysfunctional families. Our analysis demonstrates that these themes are deeply gendered and embedded in highly racialized and aged contexts, often with reference to class. We resist universalizing discourses on experiences of children (James and Prout 1997) precisely because the documented courtroom discourse does not depict children as homogeneous. Rather, we identify cultural narratives as shared perspectives of dominant groups and consider how those perspectives "might cause the content of gender and racial stereotypes [...] to overlap in specific ways” (Ridgeway and Kricheli-Katz 2013, 295). This article provides critical insight into child sexual assault adjudication and the concurrent criminal justice practices that reproduce children's oppression and broader systems of inequality. The findings complicate common Westernized understandings of the child (Angelides 2004), suggesting that legal actors invoke particular and stereotypical cultural narratives because they most closely accord with those in dominant positions wielding institutionalized power.

\section{SCHOLARLY APPROACHES TO CHILDREN AND SEXUAL ASSAULT}

\section{ADJUDICATION}

\section{Rape Narratives and the Criminal Justice System}

Jill Korbin $(2003,432)$ observed that while "it is perhaps simplistic to say that both childhood and violence are culturally constructed categories, it is nevertheless the case that violence is not a unitary phenomenon nor is childhood experienced similarly everywhere. Without making this basic assumption explicit, it is impossible to understand the variability of experience involving children and violence.” The lack of research on child sexual assault remains troubling as 1 in 5 girls and 1 in 20 boys are sexually assaulted in the U.S. (Finkelhor et al. 2014). Children living within communities marked by chronic poverty and violence-- 
disproportionately African-American, Latinx and Native American--are at increased risk for experiencing sexual assault (Miller 2008; Popkin et al. 2015; Richie 2012). When these cases are prosecuted, children encounter a unique set of challenges in the courtroom.

Narratives remain crucial to understanding trials and legal outcomes as they often rest on the veracity of the victim's narrative (Estrich 1987; Flood 2012). Witnesses, attorneys, judges, and jurors participate in storytelling as narrators and audience members (Ewick and Silbey 1995; Polletta et al. 2011). Attorneys provide legally compelling narratives that convince jurors and judges of the victim’s credibility (Ewick and Silbey 1995; Taslitz 1999). They explicitly employ rape myths as "the culturally pervasive tales of proper intergender sexual behavior that affect the crafting of courtroom and rape narratives at trials" in ways that are likely to resonate with jurors (Taslitz 1999, 19). Attorneys contend that "real victims" immediately disclose their abuse, do not dress in promiscuous ways, never initiate sexual contact, and lack vindictive motives for falsifying allegations (Estrich 1987; Orenstein 2007).

Sexual assault adjudication in the midwest has long relied on heteronormative, patriarchal, and racialized discourses (Flood 2012; Gonzalez Van Cleve 2016). Historical evidence shows how attorneys invoked stereotypes about lying, promiscuous women in their defense narratives (Flood 2012). Attorneys also perpetuate racial injustice by demarcating symbolic and literal racial boundaries against minorities (Gonzalez Van Cleve 2016). Black women are particularly vulnerable to courtroom mistreatment, often subjected to "a double dose of rape myths” (Donovan and Williams 2002, 98). Attorneys habitually affirm images depicting black women as "welfare queens" and "jezebels," rendering their reports of violence dismissible (Collins 2004; Flood 2012; Taslitz 1999). 
Rape myths are differentially applied in negotiations for legitimacy and credibility. Prosecutors serve as the gatekeepers to adjudication, considering both legal and extralegal factors in their charging decisions (Frohmann 1997; Spohn and Tellis 2014). These prosecutorial practices are also applied to the children in our study. Prosecutors consider statement inconsistencies, delayed disclosure, demeanor, residential location, and moral character to evaluate whether victims conform to expectations of "real rape victims” (Frohmann 1997). Furthermore, attorneys may adhere to patriarchal cultural narratives by encouraging victims to perform gendered, racialized, and classed scripts. In Konradi’s (2007) work, women described how prosecutors instructed them to dress in ways that suggested they did not "ask for it," to appear younger, and to show recognizable signs of emotional distress during testimony. In a courtroom where children as young as four-years-old testify in open court, testimony is tied to their embodied, racialized, and gendered presence in the courtroom.

\section{Children and Credibility}

Common beliefs uphold a unique set of behavioral expectations for children following sexual assault. These myths assert that children sustain physical injuries, immediately disclose the assault to adults, and are manipulated by authority figures to falsely report (Cheit 2014; Cossins 2009; Whittier 2009). Myths facilitate the condemnation of mothers for allowing their child to be sexually assaulted, while the actions of the perpetrator are downplayed (Bernard 2001; Carter 1999; Cromer and Goldsmith 2010; McGuffey 2005). Despite age of consent statutes and, consequentially, the inadmissibility of consent defense arguments, research shows that just as women are met with doubt when they report sexual assault, the justice system remains skeptical of children’s testimony (Cheit 2014; Staller and Vandervort 2010). Questions arise concerning young people's cognitive abilities, signs of visible trauma, memory, 
trustworthiness, and moral character (Brennan and Brennan 1988; Cossins 2009; Fontes and Plummer 2010). Many children do not immediately disclose due to embarrassment or fear of retaliation (Fontes and Plummer 2010), and documented physical evidence is rare (GoodmanDelahunty, Cossins, and O'Brien 2010; Staller and Vandervort 2010). Therefore, in the absence of material evidence jurors tend to rely upon preexisting ideas and stereotypes about children during deliberations. For example, studies with mock jurors demonstrate that endorsement of rape myths directly affects their perceptions of children’s credibility (Goodman-Delahunty, Cossins, and O’Brien. 2010). Women jurors are more likely to be empathetic to child victims, and jurors generally find children under five to be more credible and less blameworthy than children over 14 (Bottoms et al. 2014; Rogers et al. 2009). We build on this scholarship by examining how court narratives draw on existing gender, racial, and age stereotypes to present legally compelling evidence of credibility

Attuned to normative understandings of childhood to analyze the role of cultural narratives produced during trials (Kitzinger 1997), this study examined how attorneys represent, reproduce, and perpetuate dominant cultural narratives about children. Scholars have noted how children in the West are perceived as innocent passive and powerless agents (Corsaro 2015; Kitzinger 1997; Woodiwiss 2014), yet popular images reflecting fearful white children are juxtaposed with images of black and brown children as "bad,” hypersexual, and undeserving (Chesney-Lind and Eliason 2006; Collins 2004; Stephens and Phillips 2003). Adults often perceive minority children as more blameworthy than white children (Bottoms, Davis, and Epstein 2004), even as they are disproportionately at risk for sexual assault in communities experiencing severe poverty and violence (Miller 2008; Popkin et al. 2015; Richie 2012). 
Drawing on ethnographic research, we analyze the legal practices and norms of reproducing and perpetuating intersecting cultural narratives in the child sexual assault trial.

\section{METHODS}

This project comes from a larger study examining institutional responses to sexual assault. The complete dataset includes over 650 court appearances encompassing jury trials, sentencing hearings, plea negotiations, and preliminary hearings. The dataset includes fieldnotes and selected trial transcripts. We used a mixed-methods qualitative design, gathering additional data from archival sources and interviews. Records were collected from the Wisconsin Consolidated Court Automation Programs (CCAP), a public system used by courtroom personnel and citizens to provide jury trial schedules, case histories, and defendants’ demographic information. The study was reviewed and approved by key Milwaukee community stakeholders and the University Institutional Review Board. Human subjects protocol and data protections prioritized confidentiality; we use pseudonyms for victim-witnesses, attorneys, judges, victim-advocates, and defendants.

Members of the research team observed 33 sexual assault jury trials in four branches of the Milwaukee County Circuit Court from May 2013 to April 2015. Seventeen of the 33 jury trials featured child victim testimony; we excluded cases that did not involve child testimony. Our subsample consisted of 18 defendants, two of whom were co-defendants. The 17 trials included 24 child victim-witnesses (22 girls and 2 boys) between ages 5 and 16 at the time the assault was reported to have occurred. Compared to the predominantly white courthouse personnel, the majority of child sexual assault cases observed involved black and Latinx children (21 of 22) and defendants (14 of 18). All defendants in the subsample were men and knew the child prior to the reported sexual assault [3]. Of the 18 defendants on trial, 13 were found guilty, 
1 was acquitted, and 4 resulted in mistrials due to hung juries. These different outcomes demonstrate the ubiquity of the narratives notwithstanding the trajectory of the trials. Each jury trial included 12 deliberating jurors, representing a wide range of races/ethnicities, ages, neighborhoods, and professions. As participant observers, all co-authors--three U.S. based ethnographers, black, white, and Asian respectively--recognize how their race and gender positions result in differential treatment and visibilities, reaffirming the social positioning of all actors within the courtroom (Gonzalez Van Cleve 2016).

The duration of jury trials varied, generally lasting between two and five days. Fieldnotes were descriptive, reflexive, interpretive, and analytic. Detailing attorneys’ narratives involved close attention to each stage of the trial, including admissions of evidence, sidebars, jury selections, preliminary and final jury instructions, opening statements, presentations of the evidence, and closing arguments. Extensive fieldnotes documented dialog, gestures, and interactions among courtroom actors. Short jottings of conversations and statements, "off-therecord” sidebars, or casual meetings in the hallways and elevators of the courthouse were written during breaks (Emerson, Fretz, and Shaw 2011).

Staller and Vandervort $(2010,7)$ note that "legal narratives--particularly the opening and closing arguments of counsel--utilize preexisting components familiar to their constructors from stories they have read, heard, watched or told.” These preexisting components include dominant cultural narratives about childhood, race, age, gender and sexuality. Employing grounded theory, the researchers developed a qualitative analytic-inductive approach during the coding process where analytic categories emerged from the data (Charmaz 2001; Glaser and Strauss 1967; Katz 2001; Patton 1990). Analysis began with line-by-line review of fieldnotes in open coding. The authors highlighted patterns that emerged and added analytic themes to the margins (Emerson, 
Fretz, and Shaw 2011). Sensitizing concepts regarding intersectional identity and credibility served as references to guide analysis (Blumer 1969; Crenshaw 1991; Patton 1990; Ragin and Amoroso 2011). Emerging concepts were then grouped and coded into broad representational categories in a second round. The authors discussed and confirmed analytic categories following each round of coding, expanding upon recurring analytic concepts (Charmaz 2001; Emerson, Fretz, and Shaw 2011). The third round situated broad themes into three specific theoretical narratives that emphasized gender and race. These themes were defined by the patterns that surfaced within the data (Charmaz 2001). Final analytic themes were selected by focusing on those narratives most significant to the court actors involved (Emerson, Fretz, and Shaw 2011). Moving beyond the question of conviction, the authors analyzed both the specific content of narratives and the narrative practices that reproduce inequality throughout the trial process (Choo and Ferree 2010; Polletta et al. 2011; Plummer 1995). The authors do not dispute the factual innocence or guilt of defendants, but rather expose how attorneys produce particular narratives to establish legal guilt.

\section{INVISIBLE WOUNDS, REBELLIOUS ADOLESCENTS, AND DYSFUNCTIONAL}

\section{FAMILIES}

Three central themes emerged in the analysis, illustrating the court's production of gendered, raced, sexed, and classed children through cultural narratives dictating appropriate victim behavior (Scheppele 1992; Taslitz 1999). The invisible wounds theme emphasizes the presence or absence of physical and psychological wounds, referring to the common rape myth that the raped body is a damaged body (Woodiwiss 2014). This myth is tied to gendered notions of fragility and vulnerability, even as differently gendered and raced bodies are deemed more or less vulnerable. Prosecutors worked to dismantle defense assumptions of child fragility, 
particularly for pre-adolescent children. The rebellious adolescent theme builds on positionality, labeling teenagers uniquely untrustworthy and less credible than children. Youth’s purported defiance and deceit relied on intersections of age with gender and sexuality, as adolescence is associated with the dawning of sexuality and experiences of sexual desire (Elliot 2010). Race recurrently plays into the sexualization of adolescents (Tolman 1994), as attorneys leverage stereotypes about black and brown youth as sexually libidinous and out-of-control (Miller 2008). Finally, the dysfunctional family theme positions young people in relation to the adults in their lives. Defense attorneys submit that due to on-going familial conflicts, adult members of the household manipulated the child to falsely report sexual assault. Attorneys reproduce longstanding stigmas about deviant black families, including single-parent and multigenerational households, absent fathers, and hypersexual, manipulative black mothers (Collins 2000; Flood 2012; Richie 2012; Staples 1971; Gonzalez Van Cleve 2016). Attorneys powerfully employ these themes through implied and direct reference to the child's intersectional social positioning and location in Milwaukee’s urban landscape.

\section{Invisible Wounds}

Consistent with common rape myths about injury, defense attorneys argued that "real rape” produces damage through visible physical and/or psychological wounds. These attorneys emphasized the physical and emotional fragility of the child, but specifically the girl child's vulnerable body. Though often deemed crucial to the criminal investigation by law enforcement and forensic examiners (Mulla 2014), physical evidence is absent in the majority of child assault cases (De Jong and Rose 1991). Still, defense attorneys argued that children's unmarked and undamaged bodies provided reasonable doubt that sexual assault had occurred. 
Four young black children, Angela, Jacob, Jessica and Tasha, testified before the court about how the men in their lives sexually assaulted them. In 10-year-old Angela's case, the state summoned a pediatrician to explain the lack of injury found during Angela’s medical examination. While the absence of genital injury is normal in both child and adult cases, juries often expect vaginal and vulvar wounds. The pediatrician estimated she had performed over 6,000 child abuse evaluations during her career. She explained to the jury that female genitalia are made up of injury-resistant "stretchy, mucosal tissues" that heal quickly; therefore, injuries often heal by the time they are brought to the attention of adults (Fieldnotes, State v. Wilson). The prosecutor then asked, "Do these physical findings preclude a finding of sexual abuse?” to which she responded, "Not at all." On cross-examination, however, defense counsel stressed the lack of physical findings during the medical examination and asked the pediatrician to clarify that the absence of physical evidence would not be conclusive of sexual assault, arguing that Angela's unmarked body provided reasonable doubt for the court.

Twelve-year-old Jacob’s testimony illustrated the burden of proof challenges prosecutors encountered in the absence of corroborating physical evidence but with the presence of gender, sexuality, and class stereotypes. One of only two boys in our study, 8-year-old Jacob, who was biracial, had lived in a predominantly white, low-income trailer park. The prosecution alleged that two of Jacob's neighbors, both 40-something-year-old white men, befriended him, inviting him to play video games. The defendants, one a very large and hulking presence and the second more skinny and tall, were seated together accompanied by two defense attorneys. Their large size in contrast with Jacob's slight build likely contributed to the jury's expectation of signs of physical injury (Goodman-Delahunty, Cossins and O’Brien 2010). 
Due to Jacob's inability to speak in open court, the judge allowed him to write down the graphic descriptions of non-consensual anal and oral sex. Jacob positioned himself as an unwilling participant in these sexual encounters, stating "He did it to me..." or "He made me..." Afraid to tell his parents, Jacob did not disclose the abuse until almost a year later. The defense, however, argued that Jacob’s body had neither sustained visible physical injury, nor retained DNA from either assailant. Much of the defense's opening and closing arguments used highly dramatic, even crass, speech. The attorneys wondered how Jacob was "not bleeding out of his behind" and conveyed suspicion about the lack of doctor visits when he was an "8-year-old kid having anal sex three times a week.”

Defense counsel dismissed Jacob’s testimony because he failed to display the injury expected of a young boy forced into sexual activity. Their account alleged that young boys' bodies would not be able to withstand adult penetration, tapping into cultural norms of compulsive heterosexuality and masculinity (Hlavka forthcoming) and premised on stereotypes about same-sex sexual encounters between two men (Connell 1995). In Jacob’s case, the prosecutor focused on the precise details of Jacob's testimony: how he was positioned, where lubricant was applied to his body, and what assaultive acts the defendants committed. Addressing the jurors, the prosecutor asked, “How on earth does that child know that?” Details of Jacob's testimony illustrated a particular sexual knowledge presumably unknown to children his age (Woodiwiss 2014). In the prosecutor’s closing arguments, she reiterated:

This case is ultimately about the credibility of the child and the delay in reporting--the delay of time between when Jacob was sexually assaulted and when he finally felt he could trust someone to keep him safe and tell him what happened. It means that the evidence of the crime scene is long gone. But what is the crime scene? The crime scene is Jacob’s body 
... The evidence of the crime scene is either healed or been washed away. (Trial transcript, State v. Carter and Phillips)

Defense counsel simultaneously downgraded Jacob’s emotional trauma presented throughout the trial, including his frequent bed-wetting, and his own testimony about the immense sadness and fear he experienced. Following a hung jury in the first trial, the judge later told the researchers that two men on the jury were not convinced that Jacob was sexual assaulted due to the lack of visible injury and his use of a notepad during testimony. Consequently, the case was tried twice, again ending in a hung jury. The configurations of gender and sexuality associated with this case--two male defendants and a male child--may have presented a challenge to the jury's commonplace notions of heteronormativity. While one jury accepted the lack of injury on Angela's feminized body and found the defendant guilty, the jury in Jacob’s case struggled with a similar absence on a masculinized body.

When physical evidence was presented to the court, defense and prosecution offered competing narratives about its source. In the case involving 7-year-old Jessica, attorneys variably explained the redness to her hymen observed by a nurse. For the prosecution, the injuries were evidence supporting Jessica's report that her stepfather sexually assaulted her on multiple occasions. The prosecutor reiterated the nurse's observation during closing arguments, impressing upon the jury that the redness on her hymen was "consistent” with Jessica’s testimony that her stepfather would: "[get] himself off but still careful. He does not want to create any kind of injury.” The defense, on the other hand, argued that because she is a child, Jessica was unable to properly care for her own body: "The redness to her hymen could have been caused by poor hygiene, bubble baths, or wiping too much” (Fieldnotes, State v. Smith). Poor hygiene is a significant trope in racializing and class-positioning a body, introducing a 
contrast between a clean middle-class white body, and a dirty poor black body. By indirectly positioning Jessica within raced and classed narratives, and directly implicating her as the source of her own injury, defense counsel deflected attention away from the question of whether or not she was sexual assaulted.

Along with physical corroboration, attorneys often referenced children’s psychological states to create the non-credible child (Cheit 2014). Defense counsel often claimed that children could not be "real victims" if they failed to exhibit signs of long-term harm such as bedwetting, “acting out,” or emotional trauma during court testimony. For example, defense questioned 16year-old Tasha’s report that she was sexually assaulted by her father beginning at age seven because her behavior failed to alert adults that something traumatic happened to her. Throughout her court testimony, Tasha calmly described numerous occasions in which her father climbed into her bed and sexually assaulted her. For defense counsel, Tasha’s composure on the stand and her perseverance prior to trial were evidence that she had not experienced sexual assault: No one saw anything; there were no bad grades, no bedwetting, she’s not afraid of touching, no trauma, no acting out. Being sexually assaulted is a traumatic event; that child will be affected; will have a reaction; will remember details! That’s human nature! . . . She doesn’t look like a common sexual assault child victim. (Fieldnotes, State v. Young) Referring to trauma as "human nature," defense denied variation in responses to sexual violence while simultaneously highlighting the common and expected signs. His portrayal of Tasha, a young black girl, as untraumatized suggested that her reactions to sexual assault were abnormal and therefore unconvincing. Black girls who appeared emotionally strong during testimony contradicted gendered and raced expectations of emotional performances (Donovan and Williams 2002; Konradi 2007). The prosecutor accused defense counsel of “blaming the victim,” 
noting that there is nothing in the record about "normal reactions to sexual assault because there are none.” The prosecutor challenged defense assertions that Tasha did not meet common expectations of "real victims," asking Tasha to explain why she chose to stay silent and "block out” her father's abuse:

Prosecutor: "You seem very emotionless as you describe these things."

Witness: “Cause there’s some things I can’t change.”

Prosecutor: "Why didn’t you tell? Why did you keep it a secret?”

Witness: "I thought it was normal at first, then I was too scared to tell because it was my dad. My mom raised me not to tell adults what I think they should do.” (Fieldnotes, State v. Young)

Through this exchange, the prosecutor aimed to present Tasha as affected by her father's sexual assault, even though her testimony was designated “emotionless.” Tasha explained that her silence was due, in part, to her social position and what she understood to be appropriate childadult relationships. Child victims, viewed as inherently fragile and vulnerable, are compromised when the jury cannot see their physical and psychological injuries. Therefore, attorneys work to amplify or diminish evidence of “damage,” even as they reproduce rape myths through the narratives they weave. Consider also that black girls are often less likely to trust the criminal justice system and frequently remain silent despite the threat of future violence (Crenshaw 1991; Miller 2008). Tasha’s case demonstrates the complicated and contested positons of power as it relates to social position within the family and within the black community. Black women experience the "trap of loyalty" (Richie 2012, 44) wherein commitment to their families and communities reinforces individual vulnerability to victimization. This broader narrative about 
race and gender also is evidenced in the additional themes: rebellious adolescents and dysfunctional families.

\section{Rebellious Adolescents}

Age distinctions are formally recognized in legal statutes in which the seriousness of the crime is aggravated in cases involving children under the age of 13 (Wisconsin Statute 948.01). Extralegally, when young victims were over age 13, defense attorneys questioned their sexual and moral character by portraying them as rebellious “teenagers.” While children of all ages were often characterized as disobedient, attorneys' characterizations of rebellious adolescents suggested they were "more adult” and more blameworthy than younger children (Westcott and Page 2002). Defense attorneys made generalized statements about the mostly black and Latina witnesses, asserting “teenagers are sometimes unreasonable and irrational” (State v. Hill), “teenagers lie” (State v. Allen), or “teenage girls want their own room” (State v. Jones), portraying adolescents as fabricating sexual assault to gain attention, earn their freedom, or get revenge.

Attorneys’ trial tactics exploited particular cultural narratives and gendered and racialized tropes to discredit adolescents in the cases with young black girls, Jasmine and Tasha, and Latinx youth, Linda, Jorge and Sofia. Prosecutors countered defense claims about the tendency of girls to lie and manipulate, arguing that these adolescents were still very much children under the law. Fourteen-year-old Jasmine accused her former neighbor of sexually assaulting her when they were both children. At the time, she was six, while he was a 12-year-old white boy. The prosecutor denied that Jasmine could be "so clever and evil" as to fabricate these "secret crimes" (Fieldnotes, State v. Miller). Fifteen-year-old Sofia testified that the defendant, a white 30something male friend of the family, sexually assaulted her following a party as her family slept 
in the next room. Afraid her parents would feel guilty, Sofia kept the assault hidden for almost a year. The defense attorney argued that Sofia was a teenager infatuated with his client. Defense stated she had been previously sexually active with her boyfriend, and she was using the defendant to hide her sexual activity. Coupled with her deviousness and lies, defense counsel argued that Sofia was using the defendant as an excuse to rebel against her controlling parents. This brazen Lolita figure painted by the defense contrasted with the reserved and nervous young woman who testified in open court. The prosecutor reminded jurors of the devastating impact on Sofia’s family and the difficult process of testimony itself:

What motive to fabricate this does Sofia have? Why would she want to keep repeating it? Sofia had to tell a room full of strangers what happened to her. She had nothing to gain from this! She did not tell her parents because she wanted to protect them. Consider her demeanor. She is not here to get back at somebody. There is no bad blood between them (Fieldnotes, State v. Jones).

The prosecutor asserted that no one would repeat such graphic detail to "a room full of strangers" unless they indeed had experienced that abuse. Defense counsel portrayed another Latina witness, 16-year-old Linda, as rebelling against her step-father who was accused of sexually assaulting her. Linda's mother, a convincing witness for the defense, testified in Spanish through a court interpreter that Linda did not like her strict stepfather. As the Latino head of their observant Catholic family, he refused to allow Linda to wear make-up or "sexy" clothing.

At times, prosecutors refuted the portrayal of teenage girls as rebellious by displaying pictures of them as young children to jurors. In 16-year-old Tasha's case, the prosecutor, a white woman, held up an old photo of Tasha with youthful beaded hair from the time of the assault. By characterizing adolescents of color as child-like, prosecutors aimed to combat cultural narratives 
of rebellious, lying, and manipulative black and brown girls, stating: "This is the little girl, not the young woman you saw on the stand” (Fieldnotes, State v. Young). Prosecutors worked within the confines of common cultural stereotypes to physically depict youth of color as deserving of the same sympathy and legal protection afforded to younger white children. Black girls were additionally vulnerable because they were often perceived as older than their ages and consequently more responsible for the sexual violence perpetrated against them (Bottoms et al. 2004). In one case, the prosecutor paced back and forth in front of the jury, displaying a photograph of 10-year-old Angela as a younger girl:

Angela is an average girl who likes to sing and dance to artists like Beyoncé and Chris Brown; a girl who enjoys surprise birthday parties and winning family dance competitions. This girl - according to the defendant - was the one who initiated sexual contact (Fieldnotes, State v. Wilson).

Here, the prosecutor emphasized Angela’s “child-specific attributes” (Kitzinger 1997, 165) such as surprise birthday parties, seeking to convince jurors that she was too innocent to initiate sexual contact with an adult man, her black biological father. Cultural narratives surrounding adolescent sexuality can be used both to deny the "rebellious teen" capacity to consent and to sexualize them (Elliot 2010), or even to suggest that pre-adolescent children like Angela have adolescent qualities.

Black and Latino boys encountered similar defense tactics. The prosecutor described for the court how 13-year-old Jorge’s sister’s boyfriend had sexually assaulted Jorge, using force to pin his body to the sofa, and telling him, “You're gay, I want you.” Both prosecution and defense sought to control the narrative of Jorge's adolescent sexuality. While defense counsel directly suggested that the sexual encounter was consensual rather than confront the question of consent, 
the prosecutor asked the jury to consider two separate charges of second degree sexual assault: one with, and one without, the use of force [4]. Even as the prosecutor characterized the question of Jorge’s sexuality as a "family rumor” during his closing arguments, he told the jury "It shouldn’t matter if Jorge is gay.”

Despite 13-year-old Jorge’s testimony that his attacker had pinned him, straddled his chest, and forced him, the jury only returned a guilty verdict on the first charge. This neither required them to come to consensus about the use of force, nor to weigh in on Jorge's consent or nonconsent. In a post-trial interview between the researchers and one white juror, she described the jury panel discussions about Jorge's sexuality, including the role of culture and the stigmatization of sexuality and questioning gay youth. The juror proposed that perhaps the sex had been consensual, but "Latino culture" prevented Jorge from saying so. Despite his age, the jury found it plausible that Jorge was capable of seducing his sister's boyfriend. The jury's rejection of use of force, and their discussion of a young man's experience of sexuality within "Latino culture" demonstrates the confluence of marginalized identities. Even though the law dictates that children are incapable of consent, defense attorneys speculated about male adolescent sexuality to suggest sex was consensual. Questions regarding youth crushes, infatuations, and boyfriends allowed jurors to speculate about teenage girls' and boys' sexuality and deviousness, further distancing them from mainstream images of childhood innocence (Kitzinger 1997; Woodiwiss 2014).

\section{Dysfunctional Families}

Family emerged as an important factor within attorneys' legal narratives. The majority of cases involved a defendant who was a father figure (e.g., biological father, stepfather, mother's boyfriend) or a close family friend. Defense attorneys merged the child's credibility with their 
family’s credibility. The dysfunctional family narrative was especially evident for younger children who are assumed to be firmly under their family's influence. It was also a strategy adopted in some cases with adolescent victims, including Jorge's, wherein defense counsel argued that his family pressured Jorge to report the assault because they held "deep-seated animosity” towards the defendant.

Trials often functioned as “racial degradation ceremonies” (Gonzalez Van Cleve 2016). Attorneys produced racially coded language that emphasized family lifestyle to discredit and target children's families who deviated from white, heteronormative, two-parent, middle-class households. For example, defense lambasted Sofia’s father for "acting like a jerk" and allowing alcohol and drugs into their one-bedroom home. He exploited Sofia’s family's economics as a motivation for lying, arguing that she was fed up with sharing the living room of her onebedroom house with her two younger sisters while her parents shared the only bedroom. The prosecutor, however, reminded jurors that Sofia's credibility had nothing to do with her parents' partying habits or their modest home. She proposed that, "You may disagree about what was going on that night, but that is not what this case is about. This is not about parenting; this is about the defendant!”

The dysfunctional family is also highly gendered. Both defense attorneys and prosecution employed racialized scripts of the black, promiscuous "welfare mother" and the "baby mama" (Collins 2000; Stephens and Phillips 2003). This was epitomized in one week-long trial involving four young black women. The testimony by the defendant's biological daughters, Ashley (age 19 at time of testimony) and Tiffany (age 20), and family friends and relatives Jasmine (age 13) and Rene (age 23), revealed that the black male defendant had multiple children with multiple women. Over time, Ashley and Tiffany had recanted their reports of 
sexual assault, claiming they falsely accused their father because he grounded them. Jasmine and Rene, however, remained unwavering in their testimonial accounts of sexual assault.

Both the prosecutor and defense accused women family members of manipulating the defendant's daughters to lie. The prosecutor accused their mother, the defendant's current girlfriend, of pressuring Ashley and Tiffany to recant their reports because she did not want to lose her lover. Jasmine and Rene's testimony was unaltered, she argued, because they did not reside with this dysfunctional family. Defense counsel utilized the same cultural narrative to defend his client:

This is all about intra family gossip, and lies, and innuendos. This is a highly dysfunctional family with many problems. They have a lot of feuding and horrible decision-making. This isn't a normal family ... The defendant had some [children] with [mom], and some with other people. There were various aunts who poison the minds of children. Normal families don't throw around accusations like that. It is not your job or task to judge the family. Your task is to deliberate. There is a lot of gossip ... but has it been proven? (Fieldnotes, State v. Hill)

The sexual degradation of women, and in particular mothers of color, reinforces the stigma of the black family. Attorneys impart racial hierarchy on black bodies and families as they relate them to normative images of white heteronormative relations. In doing so, defense counsel claimed black women--mothers, aunts, and children included--represent deviant womanhood always in conflict with dominant notions of hegemonic femininity (Richie 2012).

Attorneys described lying and gossip as intergenerational and "poisonous," infecting black daughters and nieces, even as the defendant remained immune. Conflict between defendants' and victims' mothers were often presented as grounds for reasonable doubt. Defense 
attorneys reasoned that resentful mothers influenced their children to lie about sexual assault to get revenge. Ten-year-old Angela's mother testified that she and the defendant had a rocky relationship and often fought in front of their children. The prosecutor played a recording of jail calls in which the defendant told his wife that he had sexual intercourse with his daughter to get back at her for cheating on him. Defense counsel still argued that Angela's mother manipulated her to lie about her father, explaining that she was "a young girl stuck in the middle of a difficult relationship between her mother and father.” Interrogating the household dynamics, defense counsel aimed to pathologize Angela's relationship with her mother.

In one case, the multiracial nature of a family flowed into pathological narratives of deviance. Zoey, 17 and white, accused her black stepfather of sexual assault. Zoey’s white mother and her stepfather's black girlfriend both testified for the defense. The prosecutor argued that the "interesting family dynamics" in which two women shared one man created barriers and burdens for disclosure:

Sacrifice! She knew her mother wouldn’t believe her and she was right. Do you think [the defendant's girlfriend], who came from out of state to defend him, is gonna help [the victim]? No! Why would she tell [the defendant's girlfriend]? Who is she going to yell to? All of these women were in love with the defendant! (Fieldnotes, State $v$ Lewis) The prosecutor's characterization of Zoey's mother and the defendant's girlfriends as desperate for love and easily manipulated spoke to Zoey's delay in disclosure for over a year. The prosecutor argued that Zoey's silence was a sacrifice to keep her family together, and she had no one she could trust. This narrative emphasized the absence of the ideal mother (Bernard 2001; Carter 1999), who serves as the protector of her child's sexuality. Failing to safeguard their children from sexual encounters, mothers--especially black mothers--were made complicit in 
their children's sexual assaults, while defendants were positioned as innocent dupes to deviant, manipulating women. Zoey’s stepfather was found not guilty of sexual assault.

\section{CONCLUSION}

This article outlines the institutional narrative practices of credibility within the child sexual assault trial. Whittier $(2016,104)$ writes that children are "fundamentally shaped by intersectional inequalities of gender, race, and class, which structure individual-level experiences, prevalence, cultural representations, and state and institutional responses.” We argue that children's experiences of sexual violence, and its particular prevalence, representation, and institutional responses, are patterned in and by courtroom personnel. Our intersectional analysis focuses on the ways that non-normative images and disadvantaged social status create and sustain particular narrative vulnerabilities. As reasons to doubt children and youth, defense attorneys emphasized the lack of physical evidence and injury on the child's body, the lack of emotion both in the aftermath of the abuse and on the witness stand, the moral character of the victim, and their familial ties. Within these narratives emerge questions of consent, sexuality, and sexual history even with very young children. Adolescents--particularly teenage girls--were interrogated about their dating experiences, crushes and infatuations with defendants, while mothers were portrayed as vindictive liars who abandoned their children or coerced them into fabricating sexual assault accusations. As a result, adolescents are rendered more adult-like, and consequently more blameworthy for their assault (Westcott and Page 2002, 143). Black and Latinx youth face a deficit in their perception as innocent both because of their age and their race. Crenshaw (1991) notes that black women are particularly subjected to assumptions about sexual deviance, and our findings further support Whittier’s (2016) argument that cultural representations and state responses are relationally intersectional. 
In the context of a trial, evidence cannot be separated from narrative; in fact, "narratives often become their own best evidence” (Scheppele 1992, 162). Narrative themes not only specified expectations for the victim's prior conduct, but also their embodied and performative conduct in the courtroom. In other words, a "real rape victim" not only had to act traumatized at the time of the assault but also had to meet the standards of a traumatized victim through her demeanor and responses during testimony. The children's positionality, narrated through court actors, exposed them to that very narrative, structuring their individual-level experience, and contributing to their particular experience of testimonial violence.

Our work applies intersectional analysis, as categories of identity are inextricably linked to structures of inequality. "Structural intersectionality" involves "multilayered and routinized forms of domination” (Crenshaw 1991, 1245). It is evident in the ways in which attorneys use gender and race stereotypes and scripts about women and children to defend a patriarchal system that upholds male privilege at the expense of all women (Flood 2012). The court's practices further reproduce normative approaches to sex and gender (Butler 1990), and further perpetuate structural inequality in its responses and interventions. These patterns are clear even as the majority of child sexual assault defendants were found guilty (14 out of 18 cases). Sexual assault scholarship points out that prosecutors' concerns with case outcomes affect which cases are dismissed, and often supersede the needs of victims (Konradi 2007; Spohn and Tellis 2014). Convictions or case outcomes do not center the processes of power within the justice system that reproduces experiences of testimonial violence and broader systems of inequality that, in turn, shape legal subjectivity and reify power relationships. Recognizing the power dynamics within narrative practices does not ignore child agency or present children as "passive objects” (Corsaro 2015; Kitzinger 1997) but draws attention to the cultural narratives of childhood that are 
produced and reproduced in the trial. Defense attorneys explicitly occupy this position as they use children's testimonies, their identities, their history and that of their families, to establish reasonable doubt. Though more subtly, prosecutors also perform a similar function by framing the experiences of the victim-witness in a way that might resonate with jurors' shared beliefs. As the primary narrators and presenters of evidence, attorneys maintain much of this power within the courtroom, with victims maintaining some but limited control (Orenstein 2007).

Reconsidering approaches to adjudicating child sexual assault, and challenging the cultural narratives on which the court depends, are essential steps in dismantling the epistemic violence of testimonial injustice, particularly as it relates to children's intersectional experiences. Just outcomes are undermined by unjust processes that perpetuate structural inequality at the expense of a nuanced understanding of the lives and experiences of black and brown youth.

\section{NOTES}

[1] These figures are according to the 2010 U.S. Census figures for the City of Milwaukee.

[2] Readers will note the use of the term "victim" or "witness" and not "survivor" throughout. The term "victim" is used in this context as the research setting is adjudicative, and victimhood is both a privileged and contested legal subject position in the context of the trial. It also is the language adopted by court actors. Finally, the authors do not view victimhood as non-agentive in this context, as claiming the subject position of victim within a legal context can be both empowering and disempowering.

[3] Note that all of the defendants in this sample had relationships with the child victims we observed. This is in stark contrast to the "radical underinclusive" nature of sex offender registries, as Rose Corrigan argues, which propound an image of the stranger rapist that contrasts with the stark realities of intrafamilial and intrasocial sexual assault (2006, 267).

[4] The use of force is an aggravating factor--see Wisconsin Statutes 948.02(2) and 940.225(2)(a). 


\section{REFERENCES}

Angelides, Steven. 2004. Feminism, child sexual abuse, and the erasure of child sexuality. GLQ: A Journal of Lesbian and Gay Studies 10(2): 141-77.

Bernard, Claudia. 2001. Constructing lived experiences: Representations of black mothers in child sexual abuse discourses. Burlington, VT: Ashgate.

Blumer, Herbert. 1969. Symbolic interactionism: Perspective and method. Englewood Cliffs, NJ: Prentice-Hall.

Bottoms, Bette L., Suzanne L. Davis, and Michelle A. Epstein. 2004. Effects of victim and defendant race on jurors' decisions in child sexual abuse cases. Journal of Applied Social Psychology 34(1): 1-33.

Bottoms, Bette L., Liana C. Peter-Hagene, Margaret C. Stevenson, Tisha Wiley, Tracey Schneider Mitchell, and Gail S. Goodman. 2014. Explaining gender differences in jurors’ reactions to child sexual assault cases. Behavioral Sciences \& the Law 32(6): 789-812.

Brennan, Mark and Roslin E. Brennan. 1988. Strange language - child victims under cross examination. Wagga Wagga, N.S.W.: Riverina Literary Centre.

Butler, Judith. 1990. Gender trouble: Feminism and the Subversion of Identity. New York: Routledge.

Butler, Judith. 1993. Bodies that matter: On the discursive limits of sex. London: Routledge.

Carter, Betty J. 1999. Who's to blame? Child sexual abuse and non-offending mothers. Toronto, Ontario: University of Toronto Press.

Charmaz, Kathy. 2001. Grounded theory. Long Grove, IL: Waveland Press.

Chesney-Lind, Meda and Michele Eliason. 2006. From invisible to incorrigible: The demonization of marginalized women and girls. Crime, Media, Culture 2(1): 29-47. 
Cheit, Ross. 2014. The witch-hunt narrative: Politics, psychology, and the sexual abuse of children. New York: Oxford University Press.

Cho, Sumi, Kimberlé Crenshaw, and Leslie McCall. 2013. Toward a field of intersectionality studies: Theories, applications, and praxis. Signs 38(4): 785-810.

Choo, Hae Yeon and Myra Marx Ferree. 2010. Practicing intersectionality in sociological research: A critical analysis of inclusions, interactions, and institutions in the study of inequalities. Sociological Theory 28(2): 129-49.

Collins, Patricia Hill. 2000. Black feminist thought: Knowledge, consciousness, and the politics of empowerment, 2nd ed. New York: Routledge.

Collins, Patricia H. 2004. Black sexual politics: African Americans, gender, and the new racism. New York: Routledge.

Connell, R.W. 1995. Masculinities. Berkeley: University of California Press.

Corsaro, William. 2015. The sociology of childhood, 4th ed. Los Angeles, CA: Sage Publications.

Corrigan, Rose. 2006. Making meaning of Megan’s Law. Law and Social Inquiry 31(2): 267312.

Cossins, Annie. 2009. Cross-examination in child sexual assault trials: Evidentiary safeguard or an opportunity to confuse? Melbourne University Law Review 33(1): 68-104.

Crenshaw, Kimberlé. 1991. Mapping the margins: Intersectionality, identity politics, and violence against women of color. Stanford Law Review 43(1): 1241-99.

Cromer, Lisa DeMarni and Rachel E. Goldsmith. 2010. Child sexual abuse myths: Attitudes, beliefs, and individual differences. Journal of Child Sexual Abuse 19(6): 618-47.

De Jong, Allan R. and Mimi Rose. 1991. Legal proof of child sexual abuse in the absence of 
physical evidence. Pediatrics 88(3): 506-11.

Donovan, Roxanne and Michelle Williams. 2002. Living at the intersection: The effects of racism and sexism on black rape survivors. Women and Therapy 25(3-4): 95-105.

Elliott, Sinikka. 2010. Parents' constructions of teen sexuality: Sex panics, contradictory discourses, and social inequality. Symbolic Interaction 3(2): 191-212.

Emerson, Robert M., Rachel I. Fretz, and Linda L. Shaw. 2011. Writing ethnographic Fieldnotes, 2nd ed. Chicago, IL: The University of Chicago Press.

Estrich, Susan. 1987. Real rape: How the legal system victimizes women who say no. Cambridge: Harvard University Press.

Ewick, Patricia and Susan S. Silbey. 1995. Subversive stories and hegemonic tales: Toward a sociology of narrative. Law \& Society Review 29(2): 197-226.

Finkelhor, David, Anne Shattuck, Heather Turner, and Sherry Hamby. 2014. Trends in children’s exposure to violence, 2003-2011. JAMA Pediatrics E1-E7, doi:10.1001/jamapediatrics.2013.5296.

Flood, Dawn Rae. 2012. Rape in Chicago: Race, myth, and the courts. Chicago, IL: University of Illinois Press.

Fontes, Lisa Aronson and Carol Plummer. 2010. Cultural issues in disclosures of child sexual abuse. Journal of Child Sexual Abuse 19(1): 491-518.

Frohmann, Lisa. 1997. Convictability and discordant locales: Reproducing race, class, and gender ideologies in prosecutorial decisionmaking. Law and Society Review 31(3): 53156.

Glaser, Barney G. and Anselm L. Strauss. 1967. The discovery of grounded theory: Strategies of qualitative research. Chicago, IL: Aldine. 
Gonzalez Van Cleve, Nicole. 2016. Crook County: Racism and injustice in America's largest criminal court. Stanford, CA: Stanford University Press.

Goodman-Delahunty, Jane, Anne Cossins, and Kate O'Brien. 2010. Enhancing the credibility of complainants in child sexual abuse trials: The effect of expert evidence and judicial directions. Behavioral Sciences \& the Law 28(6): 769-83.

Hlavka, Heather. 2014. Normalizing sexual violence: Young women account for harassment and abuse. Gender \& Society 28(3): 337-58.

Hlavka, Heather. Forthcoming. Speaking of stigma and the silence of shame: Young men and sexual victimization. Men and Masculinities.

James, Allison and Alan Prout. 1997. Constructing and reconstructing childhood: Contemporary issues in the sociological study of childhood. Washington, D.C.: Routledge.

Katz, Jack. 2001. Analytic induction revisited. Long Grove, IL: Waveland Press.

Kitzinger, Jenny. 1997. Who are you kidding? Children, power and the struggle against sexual abuse. In Constructing and reconstructing childhood: Contemporary issues in the sociological study of childhood, edited by Allison James and Alan Prout. Washington, D.C.: RoutledgeFalmer.

Konradi, Amanda. 2007. Taking the stand: Rape survivors and the prosecution of rapists. Westport, CT: Praeger.

Korbin, Jill, 2003. Children, childhoods, and violence. Annual Review of Anthropology 32: 431-46.

McGuffey, C. Shawn. 2005. Engendering trauma: Race, class, and gender reaffirmation after child sexual abuse. Gender \& Society 19(5): 621-43. 
Miller, Jody. 2008. Getting played: African American girls, urban inequality, and gendered violence. New York: New York University Press.

Mulla, Sameena. 2014. The violence of care: Rape victims, forensic nurses, and sexual assault intervention. New York: New York University Press.

Orenstein, Aviva. 2007. Special issues raised by rape trials. Fordham Law Review 76(1): $1585-1608$.

Patton, Michael Q. 1990. Qualitative evaluation and research methods. Newbury Park, CA: Sage Publications.

Polletta, Francesca, Pang Ching Bobby Chen, Beth Gharrity Gardner, and Alice Motes. 2011. The sociology of storytelling. Annual Review of Sociology 37(1): 109-30.

Popkin, Susan J., Mary Bogle, Janine M. Zweig, Priya D. Saxena, Lina Breslav, and Molly Michie. 2015. "Let girls be girls: How coercive sexual environments affects girls who live in disadvantaged communities and what we can do about it.” Urban Institute. http://www.urban.org/research/publication/let-girls-be-girls

Plummer, Ken. 1995. Telling sexual stories: Power, change, and social worlds. New York: Routledge.

Ragin, Charles and Lisa M. Amoroso. 2011. Constructing social research. 2nd ed. Thousand Oaks, CA: Pine Forge Press.

Richie, Beth. E. 2012. Arrested justice: Black women, violence, and America's prison nation. New York: New York University Press.

Ridgeway, Cecilia and Tamar Kricheli-Katz. 2013. Intersecting cultural beliefs in social relations: Gender, race, and class binds and freedoms. Gender \& Society 27(3):294-318.

Rogers, Paul, Leigh Titterington, and Michelle Davies. 2009. Attributions of blame and 
credibility in a hypothetical child sexual abuse case: Roles of victim disability, victim resistance and respondent gender. International Journal of Disability, Development \& Education 56(3): 205-28.

Scheppele, Kim Lane. 1992. Just the facts, ma’am: Sexualized violence, evidentiary habits, and the revision of truth. New York Law School Law Review 37(1-2): 123-72.

Spohn, Cassia and Katharine Tellis. 2014. Policing and prosecuting sexual assault: Inside the criminal justice system. Boulder, CO: Lynne Rienner Publishers.

Staller, Karen M. and Vandervort Frank E. 2010. Child sexual abuse: Legal burdens and scientific methods. In Seeking justice in child sexual abuse: Shifting burdens and sharing responsibilities, edited by Karen M. Staller and Kathleen Coulborn Faller. New York: Columbia University Press.

Staples, Robert. 1971. Towards a sociology of the black family: A theoretical and methodological assessment. Journal of Marriage and the Family 33(1):119-38.

Stephens, Dionne P. and Layli D. Phillips. 2003. Freaks, gold diggers, divas, and dykes: The sociohistorical development of adolescent African American women’s sexual scripts. Sexuality and Culture 7(1): 3-49.

Taslitz, Andrew E. 1999. Rape and the culture of the courtroom. New York: New York University Press.

Tolman, Deborah. 1994. Doing desire: Adolescent girls’ struggles for/with sexuality. Gender \& Society 8(3): 324-42.

Westcott, Helen and Marcus Page. 2002. Cross-Examination, sexual abuse and child witness identity. Child Abuse Review 11(3): 137-52.

Whittier, Nancy. 2009. The Politics of Child Sexual Abuse: Emotion, Social Movements, and the 
State. New York: Oxford University Press.

Whittier, Nancy. 2016. Where are the children? Theorizing the missing piece in gendered sexual violence. Gender \& Society 30(1): 95-108.

Woodiwiss, Jo. 2014. Beyond a single story: The importance of separating "harm” from "wrongfulness" and "sexual innocence” from "childhood" in contemporary narratives of childhood sexual abuse. Sexualities 17(1-2): 139-58.

Amber Joy Powell is a PhD student in the Department of Sociology at the University of Minnesota. Her current research interests include crime, punishment, law, and the intersections of race and gender. Her work focuses on institutional responses to sexual violence.

Heather R. Hlavka is Associate Professor of Criminology and Law Studies in the Department of Social and Cultural Sciences. Her research joins socio-legal studies and social control to focus on sexual violence.

Sameena Mulla is Associate Professor of Anthropology in the Department of Social and Cultural Sciences. Her research is at the intersection of legal and medical anthropology, and focuses on sexual assault forensic nursing, adjudication and trial practices in the U.S. 